\title{
FACULTY DEVELOPMENT
}

\section{Faculty Development: Who, What, Why, Where, When, and How?}

\author{
Stuart T. Haines, PharmD, ${ }^{\mathrm{a}, \mathrm{b}}$ and Adam M. Persky, PhD ${ }^{\mathrm{a}, \mathrm{c}}$ \\ ${ }^{a}$ Guest Editor, Faculty Development Theme Issue, American Journal of Pharmaceutical Education \\ ${ }^{\mathrm{b}}$ School of Pharmacy, University of Maryland, Baltimore, MD \\ ${ }^{c}$ Eshelman School of Pharmacy, University of North Carolina, Chapel Hill, NC
}

Developing people - helping them become more capable, conscientious, and confident - is the fundamental mission of any academic institution. It is what they do and why they exist. At health professions colleges and schools, faculty members spend much of their time communicating the accumulated knowledge, skills, and values of the profession and providing structured opportunities for learners to develop the competencies needed to deliver contemporary health-related services. Through scholarly work, faculty members discover new insights, conceptualize and refine models, and implement and evaluate practices relevant to the professional communities they serve - in essence developing the new knowledge, skills, structures, and processes needed to improve health and make health care more effective, efficient, and safe. Students, practitioners, and patients rely on faculty members to develop them. But who develops the faculty members? Who helps them become more capable, conscientious, and confident? The answer, it seems, is they must develop each other.

New faculty members often arrive with well-developed skills as practitioners or researchers, but few have received formal training as teachers. Fewer still have had formal training as academic administrators and leaders. Mid-career and late-career faculty members also have developmental needs as their careers progress and as they take on new roles and responsibilities. Interest in faculty development has swelled as the need for and number of faculty members in health professions schools has surged. Calls for action have spurred many institutions to implement formal mentoring programs, offer faculty development seminars, and create communities of practice. ${ }^{1,2}$ In this theme issue of the Journal, we explore various models of faculty development - formal and informal, large and small, internal and external, face-to face and online.

The Journal received more than 35 manuscript proposals for this theme issue on faculty

Corresponding Author: Stuart T. Haines, Pharm.D., Department of Pharmacy Practice and Science, University of Maryland School of Pharmacy, 20 North Pine Street, 4th Floor, Baltimore, MD 21201. Tel: 410-205-9145. E-mail: shaines@rx.umaryland.edu development - testament to the degree of interest in the topic. It was unfortunate that we could not publish them all. It was clear from the proposals we received that much time, energy, and resources are being expended on faculty development. What is less clear is whether these efforts are effective. All too often faculty development is undertaken without considering and explicitly stating what the program goals are. In many cases, evaluation is an afterthought. Systematic reviews have concluded that the body of literature regarding faculty development in the health professions is far from robust and most reports lack scientific rigor. ${ }^{3,4}$ Admittedly, methods for measuring meaningful outcomes remain a bit primitive. Moving forward, the academy sorely needs clearly defined metrics and robust tools to capture data. Further, we need qualitative information regarding organizational structures and contextual factors that increase the likelihood that a faculty development program will be successful. In short, we still have a lot to learn.

For those institutions that wish to develop a faculty mentorship program or need to re-engineer an existing one, the manuscript entitled "A Checklist for the Development of Faculty Mentorship Programs" by Law and colleagues is an invaluable resource with a useful checklist of key considerations. ${ }^{5}$ Should a college or school fund and staff a Center for Teaching and Learning? Or would a faculty development committee appointed by the Dean or a community of practice self-formed by a committed few be more effective? These questions are explored in the manuscript by Lancaster and colleagues entitled "Faculty Development Program Models to Advance Teaching and Learning Within Health Science Programs."

Also in this issue of the Journal, Jackevicius and colleagues at Western University of Health Sciences (WesternU) describe the outcomes of a faculty mentorship program where junior faculty were paired with "internal" mentors - senior faculty members with appointments at WesternU. ${ }^{7}$ Similarly, Haines and Popovich describe a faculty mentoring program at Palm Beach Atlantic University where junior faculty were paired with "external" mentors senior faculty members with full-time appointments at other colleges and universities. ${ }^{8}$ Both programs resulted in modest 


\section{American Journal of Pharmaceutical Education 2014; 78 (5) Article 97.}

but statistically significant increases in scholarly activity within 3 years of initial program implementation, and participant feedback was very positive. ${ }^{7,8}$ Sicat and colleagues describe a successful university-wide community of practice, bringing together faculty members from several health professional schools with a common interest in teaching. ${ }^{9}$

Several innovative and focused approaches to faculty development are described in 4 additional manuscripts published in this theme issue. Edwards and colleagues at Northeastern University implemented a reflective teaching challenge whereby faculty members were encouraged to "try something new" in either the classroom or experiential learning environment. ${ }^{10}$ Sturpe and Schaivone explore the potential benefits of and best practices for conducting objective structure teaching exercises (OSTEs) for faculty and preceptor development. ${ }^{11}$ Online social media platforms connect people in ways that were not imagined a decade ago. In the manuscript entitled "A Nontraditional Faculty Development Initiative Using a Social Media Platform," Penick-Brock and colleagues discuss how a fantasy football league (dubbed the Cat Flight League) contributed to the professional development and success of the league's participants. ${ }^{12}$ Lastly, Clapp and colleagues at Regis University implemented a unique faculty orientation program designed to enhance non-pharmacist faculty member's awareness of contemporary pharmacy practice. ${ }^{13}$ As increasing numbers of non-health professionals become faculty members at health professions colleges and schools, mechanisms for familiarizing them to contemporary health care delivery models as well as the roles and responsibilities of various health professions is increasingly important. All of these faculty development strategies show promise as a means to help faculty members become more capable, conscientious, and confident.

To the authors whose papers are included in this issue, we are grateful to you for sharing your vision and passion. To the readers, we hope you find inspiration here.

\section{ACKNOWLEDGEMENTS}

This theme issue would not have been possible without the thoughtful contributions of Donna Qualters, PhD, Director of the Center for the Enhancement of Learning at
Tufts University, and Laurie Richlin, $\mathrm{PhD}$, Professor and Chair of the Department of Medical Education at Western Michigan University School of Medicine, who served on the theme issue selection committee. Narrowing down the many submissions and choosing a select few that would have the greatest impact was no easy task!

\section{REFERENCES}

1. Boyce EG, Burkiewicz JS, Haase MR, et al. Essential components of a faculty development program for pharmacy practice faculty. Pharmacotherapy. 2008;28(10):245e-268e.

2. Steinert Y. Faculty development: from workshops to communities of practice. Med Teach. 2010; 32(5): 425-8.

3. Leslie K, Baker L, Egan-Lee E, Esdaile M, Reeves S. Advancing faculty development in medical education: a systematic review. Acad Med. 2013; 88(7): 1038-45.

4. Steinert Y, Mann K, Centeno A, Dolman D, Spencer J, Gelula M, Prideaux D. A systematic review of faculty development initiatives designed to improve teaching effectiveness in medical education: BEME Guide No. 8. Med Teach. 2006;28(6):497-526.

5. Law AV, Bottenberg MM, Brozick AH, et al. A checklist for the development of faculty mentorship programs. Am J Pharm Educ. 2014;78(5):Article 98.

6. Lancaster JW, Stein SM, Garrelts-MacLean L, Van Amburgh J, Persky AM. Faculty development program models to advance teaching and learning within health science programs. Am J Pharm Educ. 2014;78(5):Article 99.

7. Jackevicius CA, Le J, Nazer L, Hess K, Wang J, Law AV. A formal mentorship program for faculty development. Am J Pharm Educ. 2014;78(5):Article 100.

8. Haines SL, Popovich NG. Engaging external senior faculty members as faculty mentors. Am J Pharm Educ. 2014;78(5):Article 101.

9. Sicat BL, O'Kane-Kreutzer K, Gary J, Ivey CK, Marlowe EP, Pellegrini JM, Shuford VP, Simons DF. A collaboration among health sciences schools to enhance faculty development in teaching. Am J Pharm Educ. 2014;78(5):Article 102.

10. Edwards RA, Kirwin J, Gonyeau M, Matthews SJ, Lancaster J, DiVall M. A reflective teaching challenge to motivate educational innovation. Am J Pharm Educ. 2014;78(5):Article 103.

11. Sturpe DA, Schaivone KA. A primer for objective structured teaching exercises. Am J Pharm Educ. 2014;78(5):Article 104. 12. Penick-Brock T, Assemi M, Corelli R, et al. A nontraditional faculty development initiative using a social media platform. Am J Pharm Educ. 2014;78(5):Article 105.

13. Clapp P, Calderon B, Sheridan L, Sucher B. Orientating nonpharmacist faculty members to pharmacy practice. Am J Pharm Educ. 2014;78(5):Article 106. 